\title{
Muscarinic Signaling in the Cochlea: Presynaptic and Postsynaptic Effects on Efferent Feedback and Afferent Excitability
}

\author{
Stéphane F. Maison, ${ }^{1,2,3}$ Xiao-Ping Liu, ${ }^{2,3}$ Douglas E. Vetter, ${ }^{4}$ Ruth Anne Eatock, ${ }^{1,2,3}$ Neil M. Nathanson, ${ }^{5}$ Jürgen Wess, ${ }^{6}$ \\ and M. Charles Liberman ${ }^{1,2,3}$ \\ ${ }^{1}$ Department of Otology and Laryngology, Harvard Medical School, Boston, Massachusetts 02115, ${ }^{2}$ Eaton-Peabody Laboratory, Massachusetts Eye and Ear \\ Infirmary, Boston, Massachusetts 02114, ${ }^{3}$ Program in Speech and Hearing Biosciences and Technology, Harvard-Massachusetts Institute of Technology, \\ Cambridge, Massachusetts 02139, ${ }^{4}$ Department of Neuroscience, Tufts University School of Medicine, Boston, Massachusetts 02111, ${ }^{5}$ Department of \\ Pharmacology, University of Washington, Seattle, Washington 98195, and ${ }^{6}$ Molecular Signaling Section, Laboratory of Bioorganic Chemistry, National \\ Institute of Diabetes and Digestive and Kidney Diseases, Department of Health and Human Services, Bethesda, Maryland 20892
}

Acetylcholine is the major neurotransmitter of the olivocochlear efferent system, which provides feedback to cochlear hair cells and sensory neurons. To study the role of cochlear muscarinic receptors, we studied receptor localization with immunohistochemistry and reverse transcription-PCR and measured olivocochlear function, cochlear responses, and histopathology in mice with targeted deletion of each of the five receptor subtypes. $\mathrm{M}_{2}, \mathrm{M}_{4}$, and $\mathrm{M}_{5}$ were detected in microdissected immature (postnatal days 10-13) inner hair cells and spiral ganglion cells but not outer hair cells. In the adult ( 6 weeks), the same transcripts were found in microdissected organ of Corti and spiral ganglion samples. $\mathrm{M}_{2}$ protein was found, by immunohistochemistry, in olivocochlear fibers in both outer and inner hair cell areas. $M_{3}$ mRNA was amplified only from whole cochleas, and $M_{1}$ message was never seen in wild-type ears. Auditory brainstem responses (ABRs) and distortion product otoacoustic emissions (DPOAEs) were unaffected by loss of $\mathrm{G}_{\mathrm{q}}$-coupled receptors $\left(\mathrm{M}_{1}, \mathrm{M}_{3}\right.$, or $\mathrm{M}_{5}$ ), as were shock-evoked olivocochlear effects and vulnerability to acoustic injury. In contrast, loss of $\mathrm{G}_{\mathrm{i}}$-coupled receptors $\left(\mathrm{M}_{2}\right.$ and/or $\mathrm{M}_{4}$ ) decreased neural responses without affecting DPOAEs (at low frequencies). This phenotype and the expression pattern are consistent with excitatory muscarinic signaling in cochlear sensory neurons. At high frequencies, both ABRs and DPOAEs were attenuated by loss of $\mathrm{M}_{2}$ and/or $\mathrm{M}_{4}$, and the vulnerability to acoustic injury was dramatically decreased. This aspect of the phenotype and the expression pattern are consistent with a presynaptic role for muscarinic autoreceptors in decreasing ACh release from olivocochlear terminals during high-level acoustic stimulation and suggest that muscarinic antagonists could enhance the resistance of the inner ear to noiseinduced hearing loss.

\section{Introduction}

Acetylcholine (ACh) is the major neurotransmitter in the olivocochlear efferent pathway (Eybalin, 1993), a feedback control system to the inner ear comprising a medial olivocochlear pathway projecting to outer hair cells and a lateral olivocochlear pathway projecting to dendrites of cochlear nerve fibers (Warr and Guinan, 1979; Warr, 1992). When activated, medial olivocochlear efferents raise cochlear thresholds by decreasing outer hair cell contributions to cochlear mechanical amplification (for review, see Guinan, 1996). Activation of lateral olivocochlear

Received 0ct. 12, 2009; revised March 18, 2010; accepted April 1, 2010.

This work was supported by National Institutes of Health Grants R01 DC0188 (M.C.L.), R01 DC006258 (D.E.V.) R01 DC02290 (R.A.E.), R01 NS026920 (N.M.N.), P30 DC5029 (M.C.L.), and P30 NS047243 (D.E.V.). J.W. was supported by the Intramural Research Program of the National Institute of Diabetes and Digestive and Kidney Diseases. The skillful assistance of Leslie Dodds is gratefully acknowledged, as is the generous gift of the anti-CHT antibody from Dr. Randy Blakely of Vanderbilt University.

Correspondence should be addressed to Dr. Stéphane F. Maison, Eaton-Peabody Laboratory, Massachusetts Eye and Ear Infirmary, 243 Charles Street, Boston, MA 02114-3096. E-mail: stephane_maison@meei.harvard.edu.

DOI:10.1523/JNEUROSCI.5080-09.2010

Copyright $\odot 2010$ the authors $\quad 0270-6474 / 10 / 306751-12 \$ 15.00 / 0$ projections to afferent dendrites elicits either slow excitation or inhibition of these cochlear sensory neurons, suggesting two functional subgroups (Groff and Liberman, 2003). Cochlear perfusion of $\mathrm{ACh}$, in vivo, can mimic the effects of medial olivocochlear activation on outer hair cells (Kujawa et al., 1992) and can increase spiking activity in cochlear neurons (Felix and Ehrenberger, 1992), thus mimicking effects of one lateral olivocochlear subgroup.

Cholinergic neurotransmission is mediated by two classes of ACh receptors (AChRs): ionotropic nicotinic (n)AChRs, which are nonselective cation channels, and G-protein-coupled muscarinic (m)AChRs, which act through second-messenger systems (Caulfield, 1993; Wess, 1996). The five mAChR subtypes $\left(M_{1}\right.$ to $\mathrm{M}_{5}$ ) are divided into two major functional classes. $\mathrm{M}_{1}, \mathrm{M}_{3}$, and $\mathrm{M}_{5} \mathrm{mAChRs}$ are coupled to G-proteins of the $\mathrm{G} \alpha_{\mathrm{q} / 11}$ class and stimulate the phosphatidylinositol pathway, whereas $\mathrm{M}_{2}$ and $\mathrm{M}_{4}$ mAChRs are selectively coupled to G-proteins of the $\mathrm{G} \alpha$ family and inhibit cAMP production (Caulfield, 1993; Wess, 1996, 2004). Pharmacological manipulation of hair cells in vitro as well as targeted deletion of receptor subunits in vivo show that medial 
olivocochlear effects on outer hair cells require $\alpha 9 / \alpha 10$ nAChRs mediating an ACh-induced $\mathrm{Ca}^{2+}$ influx (Fuchs and Murrow, 1992; Blanchet et al., 1996) and subsequent activation of a $\mathrm{Ca}^{2+}$ dependent $\mathrm{K}^{+}$channel (Housley and Ashmore, 1991; Kakehata et al., 1993; Erostegui et al., 1994). Medial olivocochlearmediated suppression of cochlear responses in vivo is eliminated in mutants with targeted deletion of either $\alpha 9$ or $\alpha 10 \mathrm{nAChRs}$ (Vetter et al., 1999, 2007).

Although the role of cochlear nAChRs is well established, the function, if any, of $\mathrm{mAChRs}$ in the inner ear is poorly understood. Reverse transcription (RT)-PCR, in situ hybridization, and immunohistochemistry suggest that all five mAChR subtypes may be expressed in the mammalian cochlea, (1) in the postsynaptic targets of the cholinergic olivocochlear system, i.e., sensory hair cells (Drescher et al., 1992) or sensory neurons (Safieddine et al., 1996), (2) as autoreceptors in the olivocochlear neurons themselves (Safieddine et al., 1996), or (3) in the stria vascularis, an epithelium involved in ionic regulation of cochlear fluids with no known cholinergic innervation (Wangemann et al., 2001). Pharmacological studies of isolated hair cells (Shigemoto and Ohmori, 1991; Sziklai et al., 1996) and cochlear sensory neurons (Rome et al., 1999; Ito and Dulon, 2002) also suggest functional mAChRs. However, most in vitro work has been on immature tissue, and there are no in vivo studies of muscarinic signaling in the adult inner ear.

The aim of the present study was to study mAChR function and muscarinic signaling in the adult cochlea by evaluating cochlear phenotypes of mice with targeted deletion of each of the five $\mathrm{mAChR}$ subtypes and by mapping receptor localization via immunohistochemistry and RT-PCR on cochleas and microdissected cochlear tissues. We find no evidence for a functional role for $\mathrm{G}_{\mathrm{q}}$-coupled mAChRs $\left(\mathrm{M}_{1}, \mathrm{M}_{3}\right.$, or $\left.\mathrm{M}_{5}\right)$. However, $\mathrm{G}_{\mathrm{i}}$-coupled $\mathrm{mAChRs}\left(\mathrm{M}_{2}\right.$ and $\left.\mathrm{M}_{4}\right)$ are expressed postsynaptically in cochlear neurons, in which they mediate the slow excitatory effects of lateral olivocochlear activation, and presynaptically in medial olivocochlear terminals in which they limit the olivocochlear protective effects in the outer hair cell area.

\section{Materials and Methods}

\section{Experimental procedures}

Five mouse lines were studied, each with targeted deletion of one $\mathrm{mAChR}$ subtype. The techniques used for the creation of each mutant line were described in previous reports: $M_{1}$ nulls (Hamilton et al., 1997), $M_{3}$ and $\mathrm{M}_{5}$ nulls (Yamada et al., 2001a,b), and $\mathrm{M}_{2}$ and $\mathrm{M}_{4}$ nulls (Gomeza et al., 1999a,b). $\mathrm{M}_{2} / \mathrm{M}_{4}$ mAChR double knock-out mice were generated by intermating homozygous $\mathrm{M}_{2}$ and $\mathrm{M}_{4} \mathrm{mAChR}$ single knock-outs (Zhang et al., 2002). All mutant mice lacking mAChRs were viable, fertile, and appeared generally healthy. None of the mutant mouse strains displayed gross behavioral or morphological abnormalities.

All mutant lines were created as hybrids of 129 strains (stem cell donor) and C57BL/6NTac (maternal strain) and then backcrossed with C57BL/6NTac mice for $>10$ generations. For all lines, homozygous animals and matching wild types were shipped from the laboratories of origin to the Massachusetts Eye and Ear Infirmary. The care and use of the animals was approved by the animal care committee of the Massachusetts Eye and Ear Infirmary.

\section{Gene expression}

Single-cell isolation in neonates. Cochleas of wild-type mice of both genders were dissected at postnatal day 10 (P10) to P13 in Leibovitz-15 medium, $\mathrm{pH}$ 7.4. For isolation of single inner or outer hair cells from the organ of Corti, dissected cochlear coils from the apical or middle half-turns were pinned to a glass coverslip in an extracellular solution comprising the following (in mM): $10 \mathrm{NaCl}, 6 \mathrm{KCl}, 1.5 \mathrm{CaCl}_{2}, 140 \mathrm{Na}-$ gluconate, 2 Na-pyruvate, 10 glucose, 10 HEPES, and $0.5 \mathrm{MgCl}_{2}$. Sam- pling from the apical-most quarter turn was avoided, given the many anatomical irregularities at the extremes of the cochlear duct. For aspiration of single spiral ganglion cells, the modiolus was extracted and treated with collagenase type IV $(0.5 \mathrm{mg} / \mathrm{ml})$ and trypsin $(2.5 \mathrm{mg} / \mathrm{ml})$ at $37^{\circ} \mathrm{C}$ for $30 \mathrm{~min}$ and then triturated with a pulled Pasteur pipette. Cells were allowed to settle in Leibovitz-15 medium on a poly-D-lysine-coated glass-bottom culture dish for 2-4 h. Individual identified cells were aspirated with a glass electrode of tip diameter 5-10 $\mu \mathrm{m}$ under visual guidance with Nomarski optics (ganglion cells were readily distinguished from satellite cells, as confirmed in separate experiments with whole-cell patch-clamp recordings). The pipette tip was then broken and its contents expelled into a microcentrifuge tube containing PicoPure RNA Isolation kit (Molecular Devices-Arcturus) extraction buffer and RNAase inhibitor. Sample pools, typically consisting of 6-20 individual cells of one type, were purified with the PicoPure kit and amplified by in vitro transcription using the MessageBOOSTER cDNA Synthesis kit for quantitative PCR (Epicenter Biotechnologies).

Cochlear microdissection in adults. Cochleas were harvested from adult mice (6-8 weeks old) of both genders. After the animals were killed and decapitated, the brain and both bullas were removed and placed immediately into a $35 \mathrm{~mm}$ sterile Petri dish filled with RNAlater RNA stabilization reagent (Qiagen). The inner ear was then exposed using forceps, and vestibular end organs were separated from the cochlea using a sterile surgical blade. Cochleas were transferred to a new Petri dish containing RNAlater. A small puncture was performed at the apex, and the bony capsule was removed using a right-angle microprobe (Fine Science Tools), thereby exposing the membranous cochlea. Tissues of interest (spiral ganglion, organ of Corti, or nerve trunk) were dissected with microscissors, fine forceps, and a microknife fashioned from razorblade chips. Spiral ganglion samples were taken from all cochlear turns; organ of Corti samples were easier to obtain cleanly from the apical half of the cochlea, and thus the sample is biased against basal regions. Once microdissected, tissue samples were stored in a DNAase-RNAase-free polypropylene tube and immediately frozen in liquid nitrogen until completion of two to six dissections. Tissue samples were grouped by categories and added to $1 \mathrm{ml}$ of Trizol Reagent (Invitrogen) before being homogenized using the Omni Tip Homogenizing kit (Omni International). RNA was prepared according to instructions of the manufacturer of Trizol Reagent. cDNA synthesis with integrated removal of genomic DNA contamination was then performed using the QuantiTect Reverse Transcription kit (Qiagen).

For both immature and adult tissues, the final cDNA product was used as template for amplification with primers for transcripts of mAChRs (Table 1) and cell-type-specific markers: (1) an AMPA-type glutamate receptor (GluR2) expressed in spiral ganglion cells (Chen et al., 2007), (2) the calcium sensor otoferlin expressed in inner hair cells (Roux et al., 2006), and (3) the calcium buffer oncomodulin expressed in both inner and outer hair cells (Hackney et al., 2005). Each primer $(0.5 \mu \mathrm{M})$ was combined with $0.2 \mathrm{~mm}$ dNTPs, $2.5 \mathrm{U}$ of TaqDNA Polymerase, and 1.5 $\mathrm{mm} \mathrm{MgCl}$ in $48 \mu \mathrm{l}$ of PCR buffer. The following PCR program was then run: $94^{\circ} \mathrm{C}$ for $2 \mathrm{~min} ; 40$ cycles of $94^{\circ} \mathrm{C}$ for $30 \mathrm{~s}, 55^{\circ} \mathrm{C}$ for $30 \mathrm{~s} \mathrm{(annealing}$ temperature set $5^{\circ} \mathrm{C}$ below $\left.\mathrm{T}_{\mathrm{m}}\right), 72^{\circ} \mathrm{C}$ for $1 \mathrm{~min}$; and $72^{\circ} \mathrm{C}$ for $10 \mathrm{~min}$. The amplified products were separated on a gel of $1 \%$ agarose, stained with ethidium bromide, and visualized on a UV transilluminator. For each primer set, a set of negative controls was prepared, substituting water for the reverse transcriptase, Taq polymerase, or cDNA. In these cases, no bands were observed on agarose gels with any primer tested in these control samples (data not shown). To confirm PCR product identity, amplified DNA was purified using QIAquick PCR Purification kit (Qiagen) and sequenced (Massachusetts General Hospital DNA Sequencing Core, Cambridge, MA).

Quantitative RT-PCR. Cochleas were harvested from adult mice. Wild-type materials were compared with tissue extracted from knockout mice from each of the six mutant lines. After the animals were killed and decapitated, both bullas were removed. The inner ear was exposed using forceps, and the inner ear fossa bounded by the semicircular canals was inspected to ensure that no cerebellar tissue was included. Samples were kept frozen by immersion into liquid nitrogen until four to six 
Table 1. PCR primer sets and expected amplicon size

\begin{tabular}{|c|c|c|c|}
\hline & Forward primer & Reverse primer & Amplicon (bp) \\
\hline GluR2 & 5' -TGTGTTTGTGAGGACTACGGCA-3' & 5'-GCATTCTTTGCCACCTTCATTC-3' & 453 \\
\hline Otoferlin & 5'-GCTTCCTGCCTACCCTCGG-3' & $5^{\prime}$-CAGCTTGTCAGCAATGTGATCC-3' & 635 \\
\hline Oncomodulin & 5'-TGAGCATCACGGACATCCTG-3' & 5'-ATCTTCCCGTCTCCGTCGTT-3' & 292 \\
\hline$M_{1}$ & $5^{\prime}$-GACCCTACAGACCCCTCTCC-3' & 5' -CCCTTCCTCCAGTCACAAGA-3' & 165 \\
\hline$M_{3}$ & 5' -ACAGTCGCTGTCTCCGAACT-3' & $5^{\prime}$-TCCACAGTCCACTGAGCAAG-3' & 181 \\
\hline$M_{5}$ & 5'-TTGGCTTGCACTCGACTATG-3' & 5'-GGATCTGGCACTCATCAGGT-3' & 234 \\
\hline$M_{2}$ & 5' -CGGCTTTCTATCTGCCTGTC-3' & 5' -GGCATGTTGTTGTTGTTTGG-3' & 169 \\
\hline $\mathrm{M}_{4}$ & 5' -GCCATCTTGTTCTGGCAGTT-3' & 5'-TCAGAGGGCTCTTGAGGAAA-3' & 250 \\
\hline
\end{tabular}

cochleas of each genotype were collected. Inner ears were then transferred to the appropriate volume of Trizol Reagent (Invitrogen) and homogenized using the Omni Tip Homogenizing kit (Omni International). RNA was prepared according to the instructions of the manufacturer of Trizol Reagent after a first spin performed at $2500 \times g$ to sediment debris. RNA integrity was assessed using electropherograms generated on an RNA 6000 Nano Assay Chip (Agilent Technologies) and analyzed with the 2100 Agilent Bioanalyzer system. RNA concentration was assessed using a NanoDrop system (Thermo Fisher Scientific). Quantitative RT (qRT)-PCR reactions were performed on a Mx4000 Multiplex Quantitative PCR System (Stratagene) using the one step Quantitect SYBR Green RT-PCR kit (Qiagen), HotStarTaq DNA polymerase, and primers designed to amplify the DNA fragment targeted in knock-outs (Table 1). Reactions were performed at least three times. Cycle-by-cycle and dissociation fluorescence data (melting curves) were collected. Analysis of relative fold change in gene expression was calculated as described by Stankovic and Corfas (2003) using $18 \mathrm{~S}$ rRNA as a normalizing standard whereby the normalized gene expression (NGE) during the exponential phase of the PCR can be defined as follows: $\mathrm{NGE}=E_{\mathrm{T}}^{-C_{\mathrm{T}}} / E_{\mathrm{R}}^{-C_{\mathrm{R}}}$, where $E_{\mathrm{T}}$ and $E_{\mathrm{R}}$ are, respectively, amplification efficiencies of the target and endogenous reference genes, and $C_{\mathrm{T}}$ and $C_{\mathrm{R}}$ are the mean threshold cycles for the target and reference genes, respectively.

\section{Cochlear response measures: auditory brainstem responses and} distortion product otoacoustic emissions

Electrophysiological experiments were conducted in a temperaturecontrolled sound-proof chamber maintained at $\sim 32^{\circ} \mathrm{C}$. For measurement of auditory brainstem responses (ABRs) and distortion product otoacoustic emissions (DPOAEs), mice were anesthetized with xylazine $(20 \mathrm{mg} / \mathrm{kg}$, i.p.) and ketamine (100 mg/kg, i.p.). Acoustic stimuli were delivered using a custom acoustic assembly consisting of two electrostatic earphones (EC-1; Tucker Davis Technologies) to generate primary tones and a Knowles miniature microphone (EK-3103) to record ear-canal sound pressure. Stimuli were generated digitally (digital I-O board 6052E; National Instruments). Ear-canal sound pressure and electrode voltage were amplified and digitally sampled at $20 \mu \mathrm{s}$ for analysis of response amplitudes (digital I-O board 6052E; National Instruments).

For measurement of ABRs, needle electrodes were inserted at vertex and pinna, with a ground electrode near the tail. ABR potentials were evoked with $5 \mathrm{~ms}$ tone pips $\left(0.5 \mathrm{~ms}\right.$ rise-fall with a $\cos ^{2}$ onset, delivered at $35 / \mathrm{s})$. The response was amplified $(10,000 \times)$, filtered $(100 \mathrm{~Hz}$ to 3 $\mathrm{kHz}$ ), digitized, and averaged in a LabVIEW-driven data-acquisition system. Sound level was raised in $5 \mathrm{~dB}$ steps from $10 \mathrm{~dB}$ below threshold up to $80 \mathrm{~dB}$ sound pressure level (SPL). At each sound level, 1024 responses were averaged (with stimulus polarity alternated), using an "artifact reject" whereby response waveforms were discarded when peak-to-peak amplitude exceeded $15 \mu \mathrm{V}$. During visual inspection of stacked waveforms, "threshold" was defined as the lowest SPL level at which any wave could be detected, usually corresponding to the level step just below that at which the peak-to-peak response amplitude rose significantly above the noise floor $(\sim 0.25 \mu \mathrm{V})$. For amplitude versus level functions, the wave I peak was identified by visual inspection at each sound level, and the peak-to-peak amplitude was computed.

For measurement of DPOAEs at $2 f_{1}-f_{2}$, the primary tones were set so that the frequency ratio $\left(f_{2} / f_{1}\right)$ was 1.2 and so that $f_{2}$ level was $10 \mathrm{~dB}$ below $f_{1}$ level. For each $f_{2} / f_{1}$ primary pair, levels were swept in $5 \mathrm{~dB}$ steps from 20 to $80 \mathrm{~dB} \mathrm{SPL}$ ( for $f_{2}$ ). At each level, both waveform and spectral averaging were used to increase the signal-to-noise ratio of the recorded ear-canal sound pressure, and the amplitude of the DPOAE at $2 f_{1}-f_{2}$ was extracted from the averaged spectra, along with the noise floor at nearby points in the spectrum. Iso-response curves were interpolated from plots of DPOAE amplitude versus sound level. Threshold was defined as the $f_{1}$ level required to produce a DPOAE at $0 \mathrm{~dB}$ SPL.

\section{Medial olivocochlear assay}

Mice were anesthetized with urethane $(1.20 \mathrm{~g} / \mathrm{kg}$, i.p.). A posterior craniotomy and partial cerebellar aspiration were performed to expose the floor of the IVth ventricle. To stimulate the olivocochlear bundle, shocks (monophasic pulses, $150 \mu$ s duration, 200/s) were applied through fine silver wires ( $0.4 \mathrm{~mm}$ spacing) placed along the midline, spanning the olivocochlear decussation. Shock threshold for facial twitches was determined, muscle paralysis was induced with $\alpha$-D-tubocurarine $(1.25 \mathrm{mg} /$ $\mathrm{kg}$, i.p.), and the animal was connected to a respirator via a tracheal cannula. Shock levels were raised to $6 \mathrm{~dB}$ above twitch threshold. During the olivocochlear suppression assay, $f_{2}$ level was set to produce a DPOAE $10-15 \mathrm{~dB}>$ noise floor. To measure olivocochlear effects, repeated measures of baseline DPOAE amplitude were first obtained $(n=12)$, followed by a series of 17 contiguous periods in which DPOAE amplitudes were measured with simultaneous shocks to the olivocochlear bundle and 30 additional periods during which DPOAE measures continued after the termination of the shock train. The magnitude of the efferent effect is defined as the suppression of DPOAE amplitude, i.e., the decibel difference between the mean of the first three during-shock points and the mean of the 12 pre-shock measures. In data from normal ears, the magnitude of shock-evoked efferent effects diminishes as cochlear thresholds increase (Gifford and Guinan, 1983). Thus, when wild-type animals in the present study showed lower cochlear thresholds than their littermate mutants, we adjusted (reduced) the efferent effect magnitudes measured in wild types according to a linear regression between threshold and efferent effect size obtained for a large database of 108 animals (Maison et al., 2007b).

\section{Acoustic overexposure}

Animals were exposed free-field, awake and unrestrained, in a small reverberant chamber. Acoustic trauma was produced by a $2 \mathrm{~h}$ exposure to an $8-16 \mathrm{kHz}$ octave band noise presented at $100 \mathrm{~dB}$ SPL (for permanent acoustic injury) or a 15 min exposure to the same noise at $95 \mathrm{~dB}$ SPL (for temporary acoustic injury). The exposure stimulus was generated by a custom white-noise source, filtered (Brickwall Filter with a $60 \mathrm{~dB} /$ octave slope), amplified (Crown power amplifier), and delivered (JBL compression driver) through an exponential horn fitted securely to a hole in the top of a reverberant box. Sound exposure levels were measured at four positions within each cage using a 0.25 inch Brüel and Kjær condenser microphone: sound pressure was found to vary by $<0.5 \mathrm{~dB}$ across these measurement positions.

\section{Cochlear processing and immunostaining}

Matched sets of wild-type and mutant mice were perfused intracardially for histological assessment via either plastic sections of osmiumstained cochleas or organ of Corti whole mounts immunostained for neurofilament (NF) 200 and vesicular ACh transporter (VAT) or the 
high-affinity choline transporter (CHT) to label the afferent and efferent innervation. For plastic-embedded, sectioned material, intravascular fixative was $2.5 \%$ glutaraldehyde and $1.5 \%$ paraformaldehyde in phosphate buffer. Cochleas were decalcified in EDTA, osmicated and dehydrated in ethanols and propylene oxide, embedded in Araldite resins, and sectioned at $40 \mu \mathrm{m}$ on a Historange with a carbide steel knife. Sections were mounted on slides and coverslipped.

For immunostaining of cochlear whole mounts to assess the afferent and efferent innervation, intravascular fixation was done with $4 \%$ paraformaldehyde plus $0.1 \%$ glutaraldehyde in PBS. Cochleas were decalcified, dissected into half-turns, and then incubated in $5 \%$ normal horse serum with $0.03 \%$ Triton $\mathrm{X}-100$ in PBS for $1 \mathrm{~h}$. This was followed by incubation for $\sim 19 \mathrm{~h}$ in primary antibodies: (1) mouse anti-200 kDa-NF from ICN Biomedicals at 1:50,000 or (2) mouse anti-CHT from Dr. Randy Blakely (Vanderbilt University, Nashville, TN) at 1:200, coupled with (3) rabbit anti-VAT from Sigma at 1:1000. Primary incubations were followed by $90 \mathrm{~min}$ incubations in the appropriate secondary antibodies at 1:200. Cochlear lengths were obtained for each case, and a cochlear frequency map was computed to precisely localize hair cells from the 5.6, 8.0, 11.3, 22.6, 32, 45.2, and $64 \mathrm{kHz}$ regions in each case. Confocal $z$-stacks of these seven regions from each ear were obtained using a high-resolution (1.4 numerical aperture) oil-immersion objective and $2 \times$ digital zoom on a Leica TCS SP2. Image stacks were ported to an offline processing station, in which $x-y, x-z$, and $y-z$ projections were computed and recorded using an image processing program (Amira; Visage Imaging).

For immunostaining to localize the muscarinic receptor subtypes, both cochlear whole mounts and frozen sections were used. Basic techniques were as described above. Primary antibodies included the following: rabbit anti- $\mathrm{M}_{1}$ (catalog \#M9808; Sigma), rat anti-M (catalog $^{2}$ \#MAB367; Millipore Bioscience Research Reagents), rabbit anti-M $\mathrm{M}_{3}$ (catalog \#Q4A147R; Biodesign International), and mouse anti- $\mathrm{M}_{4}$ (catalog \#MAB1576; Millipore Bioscience Research Reagents). Appropriate biotinylated secondary antibodies were used at 1:200, followed by a streptavidin-coupled AlexaFluor.

\section{Results}

\section{Expression levels and localization of muscarinic receptors in} the inner ear

Cholinergic terminals in the inner ear arise from the olivocochlear bundle. The peripheral targets of these cochlear efferent fibers include (1) outer hair cells and type II afferent terminals contacting them (via the medial olivocochlear fibers) and (2) inner hair cells and type I afferent fibers contacting them (via the lateral olivocochlear fibers) (Liberman, 1980). Thus, all four synaptic targets are sites in which muscarinic receptors might be expressed, either presynaptically or postsynaptically.

To determine which $\mathrm{mAChRs}$ are expressed in the cochlea and by which cell types, we performed RT-PCR on microdissected cells from the organ of Corti. In immature ears (P11-P13), we

\section{B Adult - cochlear microdissection}

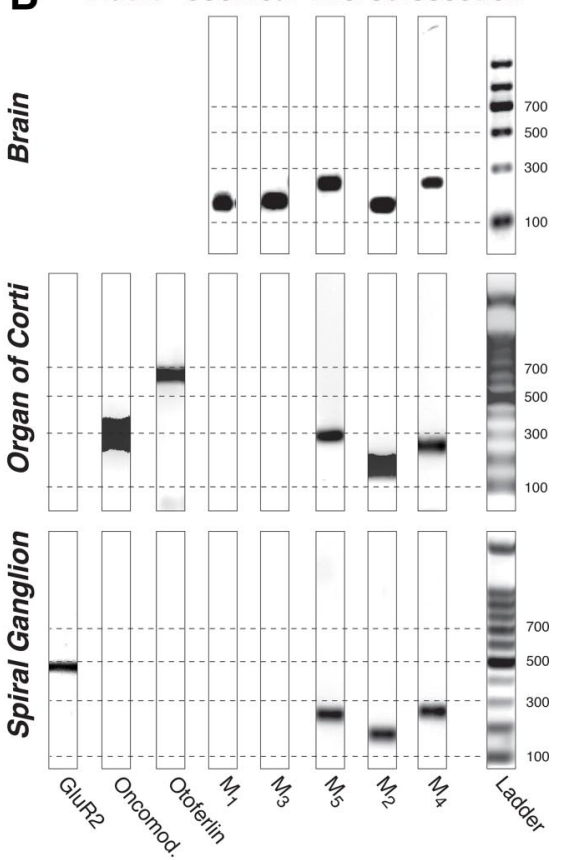

Adult - whole cochleas
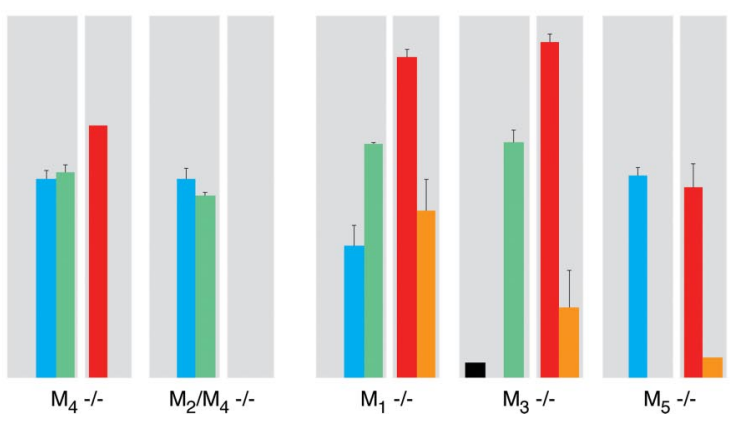

$\mathrm{M}_{5}$

Figure 1. $\quad A-C, R T-P C R(A, B)$ and $q R T-P C R(C)$ analysis of $m A C h R$ expression in wild-type mice and their compensatory upregulation/downregulation in knock-out mice $(C) M_{2}, M_{4}$, and $M_{5}$ receptors were consistently expressed in the following: $A$, inner hair cells (IHCs) and spiral ganglion neurons (SGNs) but not outer hair cells (OHCs) harvested from immature cochleas (P11-P13); $\boldsymbol{B}_{\text {, }}$ 列

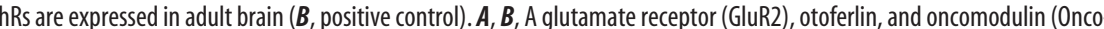
on at amplicon sizes of 100,300,500, and $700 \mathrm{bp}$. The 8-bit gel micrographs were adjusted digitally: after inversion, offset was set to 500 bp ladder band. Primer bands ( $<100 \mathrm{bp}$ ) were cut from graphs. C, Mean expression levels for mAChR mRNA are normalized to $18 \mathrm{~S}$ rRNA, after adjusting for primer efficiency, as described previously (Stankovic and Corfas, 2003). Error bars represent SEMs.

dissected out the apical or middle cochlear turn and used patchclamp pipettes to aspirate individual inner hair cells, outer hair cells, or spiral ganglion cells. Six to 12 cells were collected for each cell-type pool. RT-PCR analysis on agarose gels (Fig. $1 A$ ) revealed bands for $\mathrm{M}_{2}, \mathrm{M}_{4}$, and $\mathrm{M}_{5} \mathrm{mAChRs}$ in inner hair cells and spiral ganglion cells but not for outer hair cells. Similar results were seen for two separate pools of inner hair cells, four pools of outer hair cells, and three pools of spiral ganglion cells (data not shown), which were collected on different days and analyzed with separate RT-PCR reactions. $M_{1}$ and $M_{3}$ mRNA were never detected in any of the cell samples, although the appropriate $M_{1}$ and $\mathrm{M}_{3}$ bands were present in brain tissue (Fig. $1 B$ ) and in whole adult cochleas (see below). The AMPA-type glutamate receptor GluR2 (Chen et al., 2007), the presynaptic protein otoferlin 

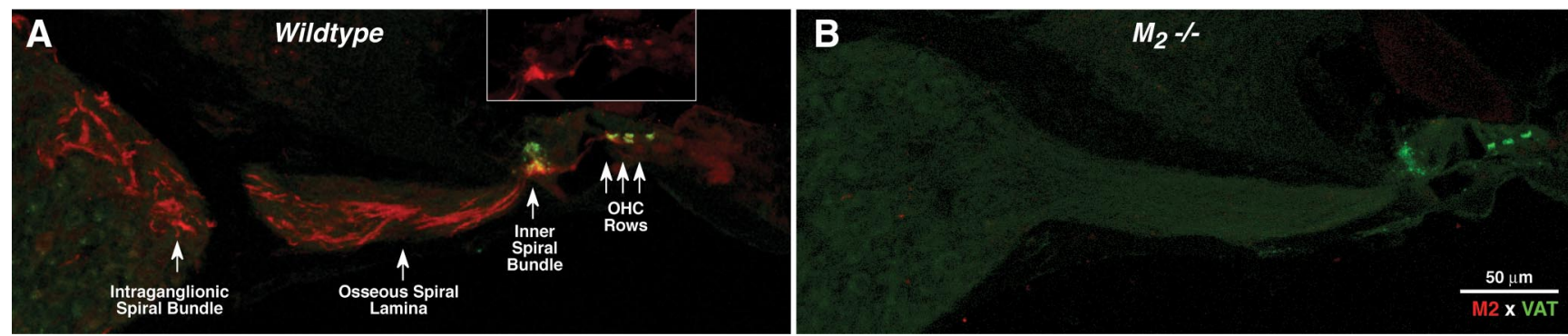

Figure 2. $\quad A, M_{2}$ receptor immunostaining (red) in adult (6-8 weeks old) wild-type cochleas is seen in olivocochlear fibers and their terminals in the inner spiral bundle under inner hair cells and under the three rows of outer hair cells (OHCs). Olivocochlear terminals also express VAT (green). $\boldsymbol{B}$, Absence of $M_{2}$ immunostaining in $M_{2}$-null mice confirms the specificity of the antibody. Photomicrographs show the cochlear duct in the upper basal turn.
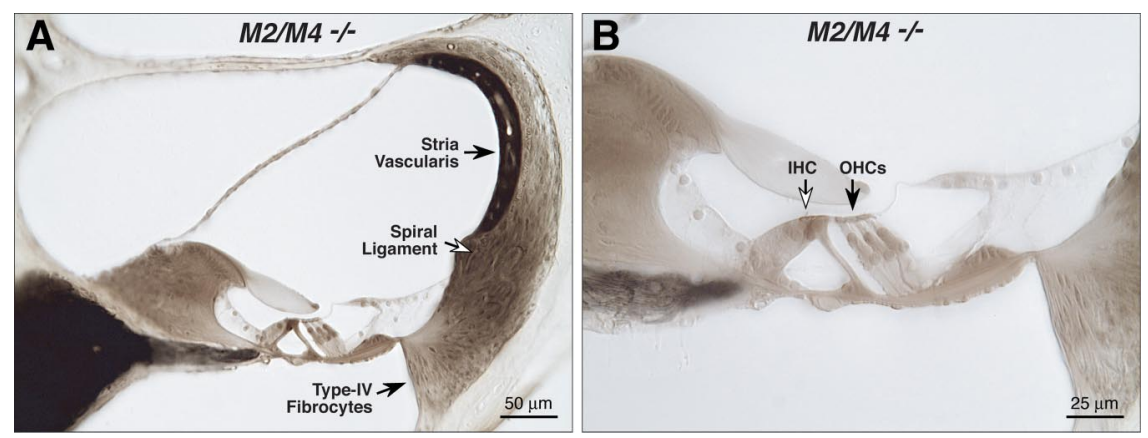

Figure 3. The cochlear duct is histologically normal in adult mice $(6-8$ weeks old) lacking $m A C h R s$, as seen in these light micrographs of osmium-stained plastic sections through the upper basal turn in an $\mathrm{M}_{2} / \mathrm{M}_{4}$ knock-out $(\boldsymbol{A}, \boldsymbol{B})$. Inner (IHCs) and outer (OHCs) hair cells are indicated by the open and filled arrows in $\boldsymbol{B}$.

(Roux et al., 2006) and the calcium buffer oncomodulin (Hackney et al., 2005) were used to verify cell type: as expected, GluR2 was seen only in spiral ganglion cell samples, otoferlin only in inner hair cell samples, and oncomodulin in both inner and outer hair cell samples.

To determine whether mRNA expression changes during cochlear maturation, we also performed RT-PCR analysis on microdissected cochlear tissues from adult ears ( 6 weeks). As shown in Figure $1 B$, both the organ of Corti samples and the spiral ganglion samples showed bands for $\mathrm{M}_{2}, \mathrm{M}_{4}$, and $\mathrm{M}_{5}$, and neither showed bands for $\mathrm{M}_{1}$ or $\mathrm{M}_{3}$ : similar results were seen for three other tissue pools derived from independent microdissections and RT-PCR reactions on additional adult mice. Thus, although RT-PCR data from adult tissue are consistent with that from neonates, $\mathrm{mAChR}$ expression cannot be localized specifically to IHCs versus OHCs, because adult hair cells do not survive the isolation procedures required for single-cell analysis. When whole cochleas were analyzed (Fig. $1 C$ ) or when the nerve trunk was included with the spiral ganglion (supplemental Fig. 1, available at www.jneurosci.org as supplemental material), an $\mathrm{M}_{3}$ band was present: $\mathrm{M}_{3}$ receptors have been detected, by RT-PCR, in microdissected stria vascularis (Wangemann et al., 2001) and may also be expressed in the nerve-root nucleus and/or parts of the cochlear nucleus that are present when the modiolus is included (Merchan et al., 1988). All PCR bands were sequenced to verify the identity of the amplicons.

To determine whether deletion of one mAChR affected expression levels of the others, quantitative RT-PCR was performed on whole adult cochleas from wild-type and knock-out lines (Fig. $1 C)$. In wild types, $\mathrm{M}_{2}, \mathrm{M}_{3}$, and $\mathrm{M}_{5}$ were expressed at higher levels than $\mathrm{M}_{4}$. Each receptor disappeared in the appropriate knockout line, and an $M_{1}$ signal was detectable in both the $M_{2}$ and $M_{3}$ knock-outs. Otherwise, deletion of $\mathrm{M}_{2}$ and/or $\mathrm{M}_{4}$ had little effect on expression of other receptors. In contrast, deletion of either $M_{1}$ or $M_{3}$ caused a significant upregulation of $\mathrm{M}_{2}$ mRNA.

We also performed immunohistochemistry for $\mathrm{mAChRs}$ on cochlear tissue. For $M_{1}, M_{3}$, and $M_{4}$, staining was weak, inconsistent, and/or unaltered in the knockout ears. The only robust and repeatable staining was seen for $\mathrm{M}_{2}$ (Fig. $2 \mathrm{~A}$, red channel). In the adult ear, $\mathrm{M}_{2}$ immunoreactivity was present in olivocochlear neurons, including their axons in the nerve trunk and the intraganglionic bundle and the osseous spiral lamina, as well as their terminals in the inner spiral bundle and underneath each of the three outer hair cell rows. Olivocochlear terminals also immunostain with a cholinergic marker: VAT (Fig. 2 , green). In the inner hair cell area, $\mathrm{M}_{2}$ immunostaining was strong throughout the cochlear spiral, whereas under the outer hair cells, the staining was only strong in the basal half of the cochlea. Absence of $\mathrm{M}_{2}$ immunostaining in the $\mathrm{M}_{2}$-null mouse confirmed the specificity of the antibody (Fig. 2 B). Examination of neonatal tissue revealed that $\mathrm{M}_{2}$ immunostaining was absent at $\mathrm{P} 9$, a time when the olivocochlear terminals are just reaching the $\mathrm{OHC}$ area.

\section{Cochlear phenotypes with targeted deletion of muscarinic receptors}

To assess the role of muscarinic receptors in the auditory periphery, we studied cochlear physiology and morphology in mice with targeted deletion of each of the mAChRs, $M_{1}-M_{5}$ as well as a double knock-out lacking both $\mathrm{M}_{2}$ and $\mathrm{M}_{4}$.

\section{Histopathology of the cochlear duct and its innervation}

Cochlear morphology in knock-outs and wild types was assessed by light microscopic evaluation of plastic sections of aldehydefixed and osmium postfixed cochleas (Fig. 3). No systematic abnormalities were seen in any structure of the inner ear, including hair cells and spiral ganglion cells, stria vascularis, spiral ligament, and all supporting structures of the cochlear duct. For each case evaluated (Table 2), serial sections through the entire cochlea were examined. Special attention was paid to the basal-turn hair cells and to the type IV fibrocytes in the spiral ligament, which are the most vulnerable elements in a number of hearingloss mouse models, including acoustic injury (Wang et al., 2002) and age-related hearing loss (Hequembourg and Liberman, 2001), as well as in other receptor mutants we have examined, 
Table 2. Numbers of mice examined from each genotype for each of the physiological and histological analyses performed in the present study

\begin{tabular}{|c|c|c|c|c|c|c|}
\hline & $M_{1}$ & $M_{3}$ & $M_{5}$ & $\mathrm{M}_{2}$ & $\mathrm{M}_{4}$ & $\mathrm{M}_{2} / \mathrm{M}_{4}$ \\
\hline \multirow[t]{2}{*}{ Thresholds (ABR/DPOAE) } & $+/+=26$ & $+1+=29$ & $+1+=22$ & $+/+=16$ & $+/+=16$ & $+/+=10$ \\
\hline & $-/-=13$ & $-/-=13$ & $-/-=14$ & $-1-=8$ & $-1-=8$ & $-/-=11$ \\
\hline \multirow[t]{2}{*}{ Efferent function } & $+/+=4$ & $+/+=8$ & $+/+=4$ & & & $+1+=5$ \\
\hline & $-l-=5$ & $-I-=10$ & $-1-=3$ & & & $-l-=6$ \\
\hline \multirow[t]{2}{*}{ Temporary noise damage } & $+/+=4$ & $+/+=6$ & $+/+=6$ & $+1+=6$ & $+1+=6$ & $+/+=7$ \\
\hline & $-1-=3$ & $-1-=3$ & $-1-=4$ & $-1-=4$ & $-/-=4$ & $-1-=7$ \\
\hline \multirow[t]{2}{*}{ Permanent noise damage } & $+/+=4$ & $+/+=8$ & $+1+=8$ & $+1+=8$ & $+1+=8$ & $+1+=7$ \\
\hline & $-1-=3$ & $-l-=5$ & $-1-=8$ & $-1-=8$ & $-1-=8$ & $-1-=7$ \\
\hline \multirow[t]{2}{*}{ Cochlear histopathology } & $+1+=3$ & $+1+=3$ & $+1+=3$ & & & $+1+=2$ \\
\hline & $-l-=5$ & $-1-=3$ & $-1-=3$ & & & $-1-=2$ \\
\hline
\end{tabular}

Histopathology and efferent function were not evaluated in the $M_{2}$ or $M_{4}$ single nulls, once we determined that the double nulls $\left(M_{2} / M_{4}\right)$ were normal by both these assays.

e.g., GluR $\delta 1, \mathrm{GABA}_{\mathrm{A}} \alpha 5$, and $\mathrm{GABA}_{\mathrm{A}} \beta 2$ (Maison et al., 2006; Gao et al., 2007).

Immunostaining of cochlear whole mounts revealed no abnormalities in either the afferent or efferent innervation in the $\mathrm{M}_{2} / \mathrm{M}_{4}$ double knock-outs (Fig. 4). Anti-NF (red) immunostaining was used to reveal all afferent and efferent fibers within the organ of Corti. To highlight the olivocochlear efferent terminals, we used antibodies to anti-VAT (green). In the outer hair cell area, the anti-VAT staining reveals the cluster of medial olivocochlear terminals under each of the three outer hair cell rows (Fig. $4 A$, filled arrowheads), as well as the small vesiculated efferent terminals in the outer spiral bundles (Fig. $4 B$, open arrowheads), in which medial olivocochlear fibers synapse with the afferent terminals of type II spiral ganglion cells contacting outer hair cells (Thiers et al., 2008). In the inner hair cell area, the anti-VAT staining reveals the profusion of small en passant terminals from the lateral olivocochlear fibers, which synapse on the peripheral terminals of type I spiral ganglion cells contacting inner hair cells, as well as on the inner hair cells themselves (Liberman, 1980). High-power confocal $z$-stacks of immunostained cochlear whole mounts, such as those in Figure 4, were acquired from two $\mathrm{M}_{2} / \mathrm{M}_{4}$ double knock-outs and one age-matched wild type at seven log-spaced cochlear locations from apex to base. Side-by-side comparison, as in Figure 4, revealed no differences among them or in comparison with similarly stained material from dozens of other wild-type mice acquired in the course of previous studies. Given a recent report that targeted deletion of a nicotinic ACh receptor leads to downregulation of the highaffinity CHT in the presynaptic terminals, despite continued expression of VAT (Krishnaswamy and Cooper, 2009), we immunostained cochleas from wild types and $\mathrm{M}_{2} / \mathrm{M}_{4}$ double nulls and found no difference in CHT immunostaining patterns (supplemental Fig. 2, available at www.jneurosci.org as supplemental material).

Given the lack of physiological phenotypes in $M_{1}, M_{3}$, or $M_{5}$ single knock-outs (see below), we did not evaluate the innervation patterns in these mutant lines.

\section{Cochlear responses to sound}

Because previous studies suggest muscarinic signaling in both outer hair cells and spiral ganglion cells (Drescher et al., 1992; Safieddine et al., 1996; Khan et al., 2002), we assessed cochlear function by both ABRs and DPOAEs, because the combination can differentiate outer hair cell-based dysfunction (reflected in DPOAEs) from that arising farther "downstream," i.e., in the inner hair cell or spiral ganglion cell (evident in ABRs). Both ABR and DPOAE data were gathered in such a way as to allow both (1) a measure of the threshold of response, i.e., the lowest stimulus level required to produce a criterion response, just above the measurement noise floor, and (2) the growth of response magnitude with sound pressure level.

Deletion of $\mathrm{M}_{1}, \mathrm{M}_{3}$, or $\mathrm{M}_{5}$, i.e., the $\mathrm{G}_{\mathrm{q}}$-coupled $\mathrm{mAChRs}$, had no impact on cochlear thresholds, as measured by either DPOAEs (Fig. 5A) or ABRs (Fig. 5B), nor on the amplitudes of suprathreshold DPOAE or ABR responses at any of the test frequencies: data are shown for $16 \mathrm{kHz}$ in Figure 5, $C$ and $D$, respectively.

In contrast, deletion of $\mathrm{M}_{2}$ and/or $\mathrm{M}_{4}$, i.e., the $\mathrm{G}_{\mathrm{i}}$-coupled $\mathrm{mAChRs}$, reduced neural response amplitudes. Figure $6 D$ shows mean amplitude-versus-level functions for ABR wave 1, the summed activity of spiral ganglion neurons, for tones at $16 \mathrm{kHz}$. Similar reductions in mean amplitude were seen at all other test frequencies. These amplitude reductions, especially for $\mathrm{M}_{2}$ and $\mathrm{M}_{2} / \mathrm{M}_{4}$ nulls, corresponded to an approximately constant decrease of $25 \%$ across all stimulus levels. Such constant-fraction response reductions, which appear largest at high SPLs, are characteristic of perturbations that modulate lateral olivocochlear effects on spiral ganglion neurons (Groff and Liberman, 2003). For the $\mathrm{M}_{2}$ nulls, differences were statistically significant by twoway $\operatorname{ANOVA}(5.66 \mathrm{kHz}, p=0.003 ; 8 \mathrm{kHz}, p=0.007 ; 11.33$ 

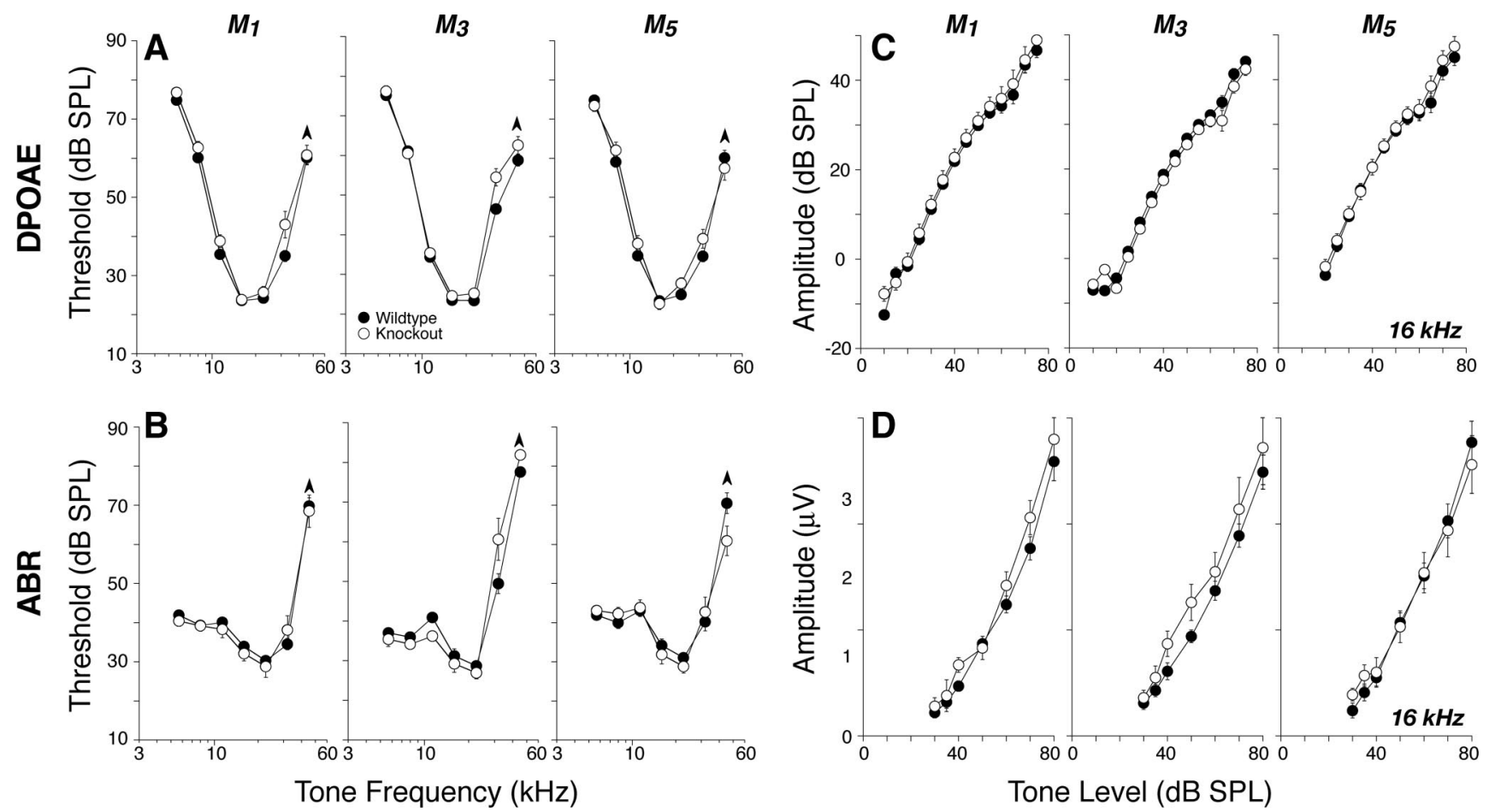

Figure 5. $A-D$, Deletion of $M_{1}, M_{3}$, or $M_{5} m A C h R s$ did not affect cochlear thresholds $(\boldsymbol{A}, \boldsymbol{B})$ or suprathreshold responses $(\boldsymbol{C}, \boldsymbol{D})$, as measured by DPOAEs $(\boldsymbol{A}, \boldsymbol{C})$ or $A B R s(\boldsymbol{B}, \boldsymbol{D})$. $\boldsymbol{A}, \boldsymbol{B}$, Mean $D P O A E$ or $A B R$ thresholds for groups of $6-8$ week mutants and wild-type controls (numbers in each group are given in Table 2). $C, D$, Mean amplitude-versus-level functions for the same animals from $A$ and $B$, as seen in DPOAEs or ABRs, evoked by tones at $16 \mathrm{kHz}$ (for DPOAEs, $f_{2}=16 \mathrm{kHz}$ ). For ABRs, only wave 1, the earliest negative-positive deflection, was measured. Error bars in all panels represent SEMs: the symbol key in $\boldsymbol{A}$ applies to all panels.

$\mathrm{kHz}, p=0.016 ; 16 \mathrm{kHz}, p=0.009 ; 22.65, p=0.003 ; 32 \mathrm{kHz}, p=$ $0.003)$. For the $M_{4}$ knock-outs, differences were significant at 8 $\mathrm{kHz}$ and above $(8 \mathrm{kHz}, p=0.04 ; 11.33 \mathrm{kHz}, p=0.034 ; 16 \mathrm{kHz}$, $p=0.018 ; 22.65 \mathrm{kHz}, p=0.007 ; 32 \mathrm{kHz}, p=0.032)$. For the double knock-out, differences were significant at $11 \mathrm{kHz}$ and above $(11.33 \mathrm{kHz}, p=0.007 ; 16 \mathrm{kHz}, p=0.004 ; 22.65 \mathrm{kHz}, p=$ $0.015 ; 32 \mathrm{kHz}, p<0.001)$.

It is noteworthy that, at the four lower test frequencies $(5.6,8$, 11.3 , and $16 \mathrm{kHz}$ ), the amplitude reductions were seen without shifts in ABR thresholds (Fig. 5B), DPOAE thresholds (Fig. 6A), or DPOAE suprathreshold response amplitudes (Fig. 6C), consistent with a specific effect on spiral ganglion cells, without any outer hair cell dysfunction. In contrast, at higher test frequencies $(22-45 \mathrm{kHz})$, there are also small but significant shifts in DPOAE (Fig. $6 A, p<0.001$ ) and ABR (Fig. $6 B, p=0.002$ ) thresholds, as well as in DPOAE suprathreshold responses (data not shown), suggesting a combination of outer hair cell and neural dysfunction in $\mathrm{M}_{2}$ knock-outs.

\section{Olivocochlear efferent function}

Medial olivocochlear fibers project to outer hair cells (Maison et al., 2003a) and form the effector arm of a negative feedback pathway, whose activation decreases the normal contribution of outer hair cells to cochlear mechanical amplification. Olivocochlear activation, by sound or by electrical stimulation in the brainstem, suppresses DPOAEs (Fig. 7A). This suppression provides a sensitive measure of olivocochlear function. Although olivocochlear suppression is mediated by nicotinic AChRs made up of $\alpha 9$ and $\alpha 10$ subunits (Vetter et al., 1999, 2007), mAChRs on either presynaptic terminals or (postsynaptic) outer hair cells could play a modulatory role (Bartolami et al., 1993). Thus, we investigated whether the loss of mAChRs affects the time course or magnitude of the olivocochlear effect.
One "run" of our olivocochlear assay (Fig. 7A) involves multiple measures of DPOAE magnitude before, during, and after a $70 \mathrm{~s}$ period of olivocochlear bundle shocks delivered at the floor of the IVth ventricle. At shock-train onset, DPOAEs are rapidly reduced. In mice, this olivocochlear suppression is maximal for tones at $11-22 \mathrm{kHz}$ and declines for higher and lower frequencies (Maison et al., 2002, 2003b), reflecting the analogous gradient in density of olivocochlear terminals along the cochlear spiral (Maison et al., 2003a). The normality of olivocochlear suppression in the mutant lines (Fig. $7 B$ ) is consistent with the normality of efferent innervation seen in immunostaining data from these mutants described above (Fig. 4).

DPOAE suppression tends to decay during the 70 s shock train (Fig. 7A). Similar decay has been observed in efferent suppression of auditory nerve response (Wiederhold and Kiang, 1970), and some portion may be attributable to $\alpha 9 / \alpha 10 \mathrm{nAChR}$ desensitization (Elgoyhen et al., 2001; Taranda et al., 2009). No anomalies were observed in the magnitude of the decay in any of the mAChR knock-out lines.

A slow enhancement of DPOAEs is clearly visible after termination of the olivocochlear shock train (Fig. 7A). This slow enhancement is not mediated by nicotinic AChRs: in contrast to the fast suppressive effect, it persists in mice with targeted deletion of $\alpha 9$ or $\alpha 10$ nAChRs (Vetter et al., 2007). This postshock enhancement is also unaffected by deletion of any of the mAChRs (Fig. 7A).

\section{Vulnerability to acoustic injury}

The olivocochlear system can protect the ear from acoustic overstimulation via its effects in both inner and outer hair cell regions (Maison et al., 2002; Darrow et al., 2007; Taranda et al., 2009). Although nicotinic AChRs are clearly involved in mediating this effect (Maison et al., 2002), mAChRs could play an important 

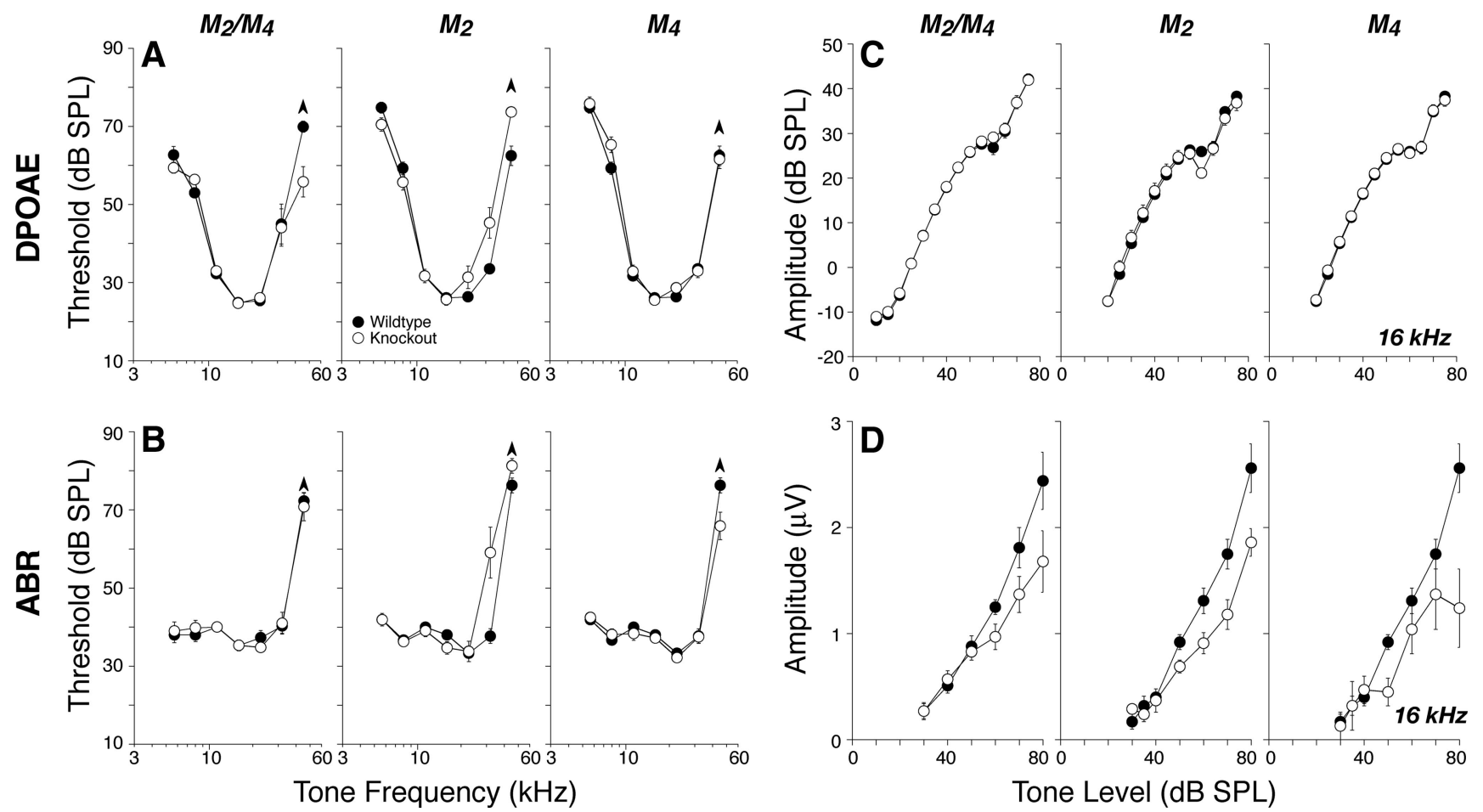

Figure 6. $\boldsymbol{A}-\boldsymbol{D}$, Deletion of either $\mathrm{M}_{2}$ or $\mathrm{M}_{4} \mathrm{mAChRs}$ or both elevated high-frequency DPOAE $(\boldsymbol{A})$ and $A B R(\boldsymbol{B})$ thresholds and reduced suprathreshold neural responses ( $\left.\boldsymbol{D}\right)$ even in midcochlear regions in which thresholds $(\boldsymbol{A}, \boldsymbol{B})$ and DPOAEs $(\boldsymbol{C})$ were normal. $\boldsymbol{A}, \boldsymbol{B}$, Mean DPOAE or ABR thresholds for groups of 6 - 8 week mutants and wild-type controls (numbers in each group are given in Table 2). $\boldsymbol{C}, \boldsymbol{D}$, Mean amplitude-versus-level functions for the same animals from $\boldsymbol{A}$ and $\boldsymbol{B}$, as seen in DPOAEs or $A B R s$ evoked by tones at $16 \mathrm{kHz}$ (for DP0AEs, $f_{2}=16 \mathrm{kHz}$ ). For $A B R s$, only wave 1 , the earliest negative-positive deflection, was measured. Error bars in all panels represent SEMs: the symbol key in $\boldsymbol{A}$ applies to all panels.
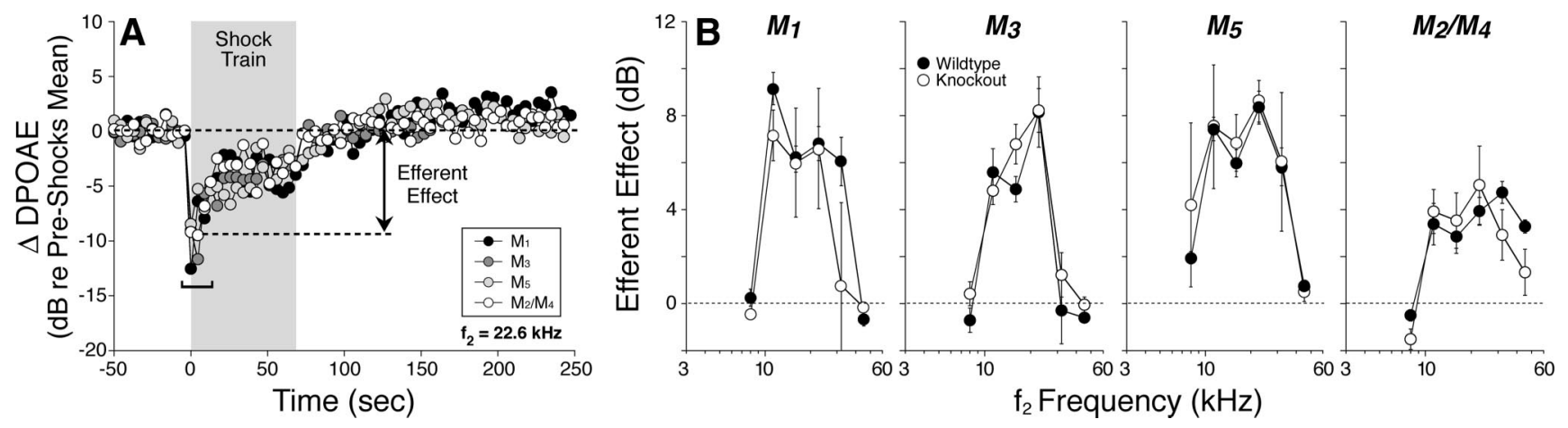

Figure 7. Cochlear effects of activating the medial olivocochlear efferents are undiminished by deletion of mAChR receptors. To assay efferent effects, DPOAE amplitudes evoked by low-level tones are measured before, during, and after delivering a 70 s shock train to the olivocochlear bundle at the floor of the IVth ventricle. $A$, One run of the assay for each $\mathrm{mAChR}$ knock-out shows DPOAE amplitudes, normalized to the mean pre-shock value. Efferent effect is defined as the difference between the pre-shock mean and the mean DPOAE amplitude for the first three measures taken after shock-train onset (i.e., during shock window). $\boldsymbol{B}$, Mean \pm SEM efferent effect size for wild-type versus mAChR-null ears for each of the four lines tested.

modulatory role. To assess vulnerability to acoustic injury, groups of mutant and wild-type animals were exposed to a noise band designed to produce either a reversible or an irreversible threshold shift, with noise exposures of $95 \mathrm{~dB}$ SPL for $15 \mathrm{~min}$ or $100 \mathrm{~dB}$ SPL for $2 \mathrm{~h}$, respectively.

Noise vulnerability was not affected by any of the single-gene deletions (data not shown); however, the $\mathrm{M}_{2} / \mathrm{M}_{4}$ double knockouts were more resistant to both temporary and permanent threshold shifts (Fig. 8). The differences were statistically significant by two-way ANOVA, for both the temporary threshold shifts (ABR, $p=0.009$; DPOAE, $p=0.001$ ) and the permanent threshold shifts (ABR, $p=0.010$; DPOAE, $p=$ 0.044). The observation that the vulnerability differences are comparable in both the DPOAE and ABR measures is consistent with an outer hair cell-based effect. Because this degree of noise-induced threshold shift, even when permanent, causes no light-microscopic histopathology in the affected sensory cells (Wang et al., 2002), the site of protection could not be verified histologically.

\section{Discussion}

Cholinergic terminals in the inner ear are from olivocochlear efferents, which, when activated by sound or electric shocks, suppress cochlear responses as part of a negative feedback loop that controls noise masking and protects the ear from acoustic injury (Guinan, 1996). Olivocochlear suppression has an onset time constant of $\sim 100 \mathrm{~ms}$ (Sridhar et al., 1995, 1997) and is mediated by nicotinic ACh receptors comprising $\alpha 9$ and $\alpha 10$ subunits (Elgoyhen et al., 1994). In the adult ear, this nicotinic receptor complex is present only on outer hair cells (Elgoyhen et al., 2001), 

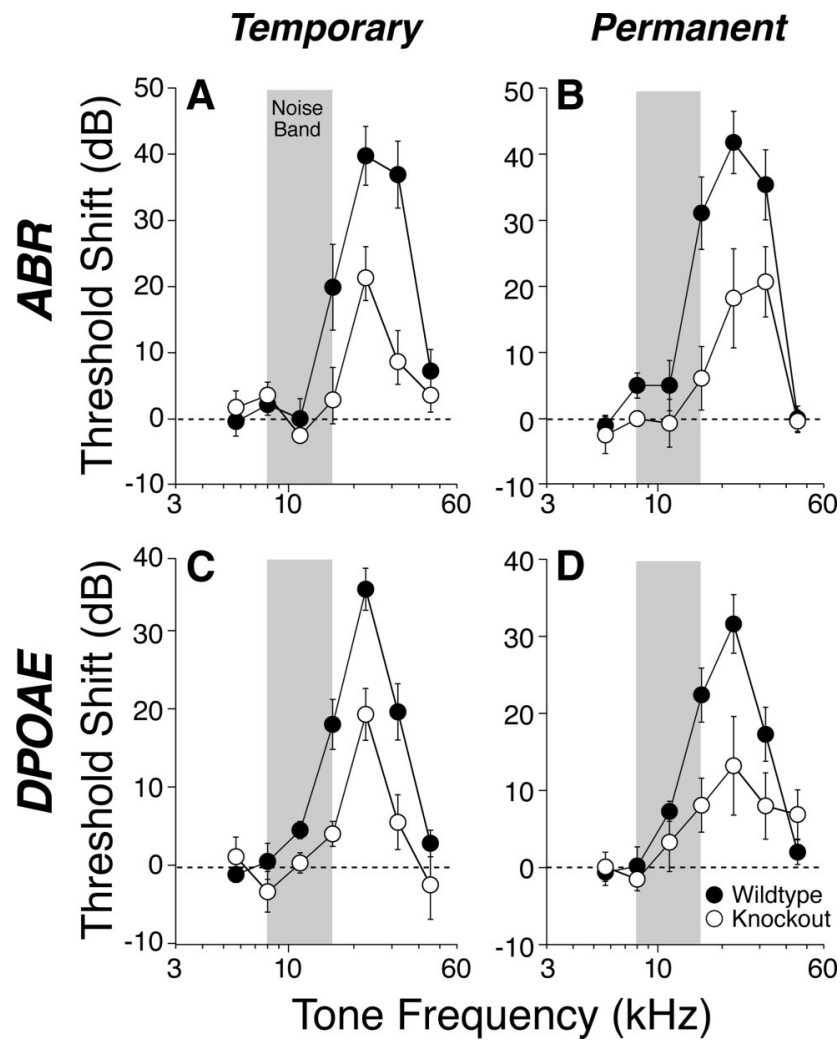

Figure 8. $\boldsymbol{A}-\boldsymbol{D}$, Vulnerability to temporary $(\boldsymbol{A}, \boldsymbol{C})$ and permanent $(\boldsymbol{B}, \boldsymbol{D})$ acoustic injury is reduced by conjoint loss of $\mathrm{M}_{2}$ and $\mathrm{M}_{4} \mathrm{mAChRs} A, C$, Mean $\pm S E M$ threshold shift for wild types versus double knock-outs, as measured $6 \mathrm{~h}$ after exposure to an 8-16 kHz noise band (gray bars) at $95 \mathrm{~dB}$ for $15 \mathrm{~min} . \boldsymbol{B}, \boldsymbol{D}$, Mean \pm SEM threshold shift for wild types versus double knock-outs, as measured 1 week after exposure to the same noise band at $100 \mathrm{~dB}$ for $2 \mathrm{~h}$. For both exposures, the threshold shifts are similar when measured by $\operatorname{ABRs}(\boldsymbol{A}, \boldsymbol{B})$ or DPOAEs $(\boldsymbol{C}, \boldsymbol{D})$. Symbol key in $\boldsymbol{D}$ applies to all panels.

and the suppressive effect arises by decreasing the normal contribution to cochlear mechanical amplification by outer hair cells. Cholinergic efferents also project to inner hair cells and to terminals of sensory neurons on both inner and outer hair cells, i.e., type I and type II spiral ganglion cells, respectively (Liberman, 1980). These four cell types, plus the olivocochlear terminals themselves, represent candidate loci for postsynaptic or presynaptic muscarinic signaling, respectively (Fig. 9).

\section{Receptor expression and localization}

RT-PCR analysis consistently found $\mathrm{M}_{2}, \mathrm{M}_{4}$, and $\mathrm{M}_{5}$ mRNA in isolated immature inner hair cells and spiral ganglion cells, and in microdissected organ of Corti and ganglion from adults (Fig. 1). $M_{1}$ or $M_{3}$ amplicons were never detected in these structures, but an $\mathrm{M}_{3}$ band was observed when the cochlear nerve trunk was included [thereby including second-order auditory neurons (Merchan et al., 1988)]. Our expression results are consistent with our knock-out physiology in that both $\mathrm{M}_{2}$ and $\mathrm{M}_{4}$ knockouts showed a cochlear phenotype, whereas the $M_{1}$ and $M_{3}$ knock-outs did not (see below).

Previous RT-PCR study in gerbil reported $\mathrm{M}_{3}$ expression in microdissected stria vascularis (Wangemann et al., 2001). Transcripts for $M_{1}, M_{3}$, and $M_{5}$ (but not $M_{2}$ or $M_{4}$ ) were amplified from whole mouse cochleas (Drescher et al., 1992), and, in rats and guinea pigs, $\mathrm{M}_{3}$ transcripts were found in microdissected organ of Corti and spiral ganglion (Safiedine et al., 1996). The failure to find $\mathrm{M}_{2}$ or $\mathrm{M}_{4}$ in the previous mouse study could be

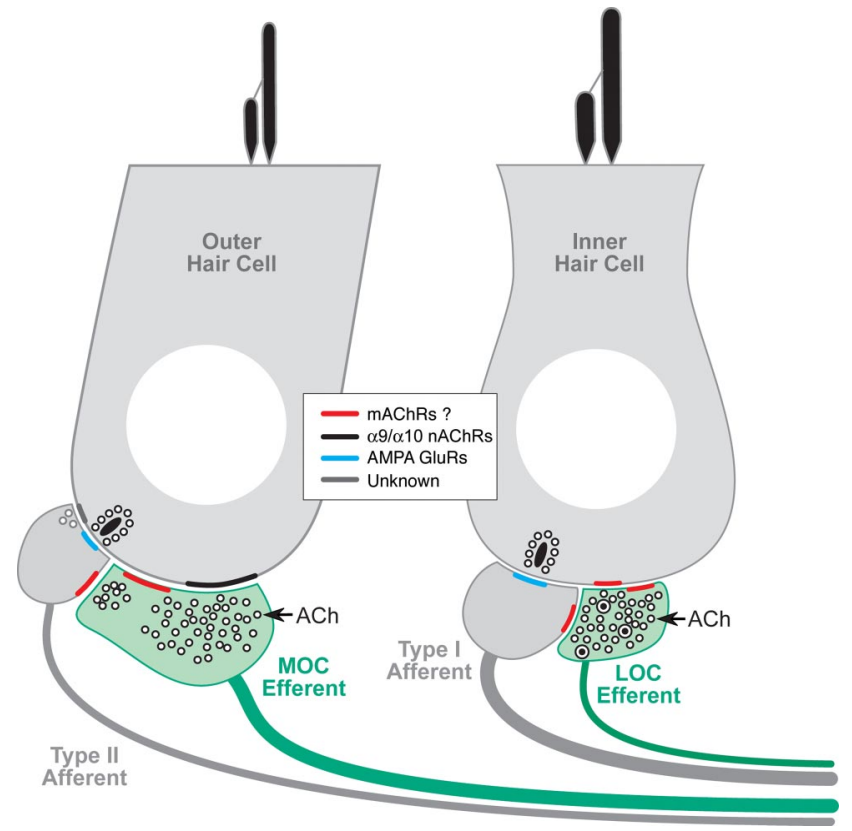

Figure 9. Schematic showing the peripheral targets of the cholinergic terminals of efferent fibers from the lateral olivocochlear ( $\mathrm{LOC}$ ) and medial olivocochlear (MOC) divisions and of the possible locations of mAChRs (see key), according to the present results.

attributable to sequence mismatches between the old primers and current databases: comparison with the target sequences (http:// www.ncbi.nlm.nih.gov/tools/primer-blast/index.cgi?LINK_ $\mathrm{LOC}=$ BlastNoResAd) reveals two mismatches for the $\mathrm{M}_{2}$ forward primer and one mismatch for the $\mathrm{M}_{4}$ reverse primer. The $1996 \mathrm{rat} /$ guinea pig study did not look for $\mathrm{M}_{2}$ or $\mathrm{M}_{4}$, and the $\mathrm{M}_{3}$ in previous RT-PCR studies could reflect sample contamination from nerve trunk or stria.

Previous immunohistochemical study reported $\mathrm{M}_{3}$ staining in outer hair cells, $M_{1}$ in inner hair cells, $M_{1}$ and $M_{2}$ in supporting cells, $M_{3}$ and $M_{5}$ in spiral ganglion cells, and $M_{5}$ in the stria vascularis (Khan et al., 2002). In our hands, antibodies to $M_{1}, M_{3}$, or $\mathrm{M}_{4}$ receptors also produced weak signals in numerous cell types (including supporting cells and fibrocytes that are not innervated by cholinergic neurons); however, the immunostaining failed to disappear in the appropriate knock-outs. In contrast, $\mathrm{M}_{2}$ immunostaining in olivocochlear fibers and terminals was robust and repeatable, and the signal disappeared in the $\mathrm{M}_{2}$ nulls (Fig. 2 ). Others have also concluded, based on analysis of brain sections from wild-type and knock-out lines, that, of all the commercially available $\mathrm{mAChR}$ antibodies, only $\mathrm{M}_{2}$ labeling is specific (Jositsch et al., 2009). The lack of $\mathrm{M}_{2}$ immunolabeling in inner hair cells and spiral ganglion cells in our material, despite our RT-PCR evidence for their expression, may reflect a lower abundance of postsynaptic versus presynaptic receptors in the inner ear.

\section{In vitro studies of muscarinic signaling}

Evidence for muscarinic signaling in the inner ear comes from several experimental approaches. Early studies used binding of the muscarinic antagonist quinuclidinyl benzilate and its competition with muscarinic agonists in cochlear homogenates to suggest the presence of mAChRs (James et al., 1983; van Megen et al., 1988). Activation of the phosphoinositide second-messenger system by carbachol and other muscarinic agonists (Niedzielski et al., 1992) constituted additional evidence. Reduction of this car- 
bachol effect by removal of the olivocochlear bundle, but not by outer hair cell destruction, suggested (presynaptic) muscarinic receptors in cholinergic efferent terminals (Bartolami et al., 1993). Lack of postsynaptic mAChRs on outer hair cells was further evidenced by their failure to bind the muscarinic antagonist quinuclidinyl benzilate (Heilbronn et al., 1995).

Evidence for muscarinic regulation of strial function comes from in vitro measurements of $\mathrm{K}^{+}$secretion as a transepithelial current (Wangemann et al., 2001). Carbachol application to the basolateral surface increases transepithelial currents and can be blocked by muscarinic antagonists. However, the functional significance of strial $\mathrm{mAChRs}$ is unclear, because there is no known cholinergic innervation of this structure.

In vitro, ACh-evoked ionic currents in hair cells disappear when the $\alpha 9 / \alpha 10$ nicotinic receptor complex is disrupted (Vetter et al., 2007) or blocked pharmacologically (Verbitsky et al., 2000); however, such studies do not assess metabotropic cholinergic effects such as second-messenger cascades or changes in intracellular $\mathrm{Ca}^{2+}$. The lack of detectable mAChR transcripts in outer hair cells (Fig. 1A) suggests that muscarinic signaling is not present. Conversely, detection of mAChR transcripts in inner hair cells suggests that muscarinic signaling could occur in these cells despite our failure to confirm $\mathrm{mAChR}$ expression at the protein level. In frog vestibular hair cells, a slow ACh-induced increase in afferent firing has a muscarinic pharmacology (Guth et al., 1986) and may arise from an mAChR-mediated increase in transmitter release from hair cells (Derbenev et al., 2005). Small muscarinic effects in avian hair cells have also been reported (Lippe et al., 2002).

In isolated spiral ganglion cells from rat (P3-P30), AChevoked increases in intracellular $\mathrm{Ca}^{2+}$ have a muscarinic pharmacology (Rome et al., 1999), and muscarinic agonists activate a large, nonselective cation conductance (Ito and Dulon, 2002). The depolarization associated with this activation should increase neural excitability in vivo, as described for cochlear nerve fibers during ACh perfusion of the inner ear (Felix and Ehrenberger, 1992).

\section{Muscarinic signaling in the adult inner ear}

The present report represents the first in vivo study of muscarinic signaling in the cochlea. Mice lacking $G_{q}$-coupled $m A C h R s ~ M_{1}$, $\mathrm{M}_{3}$, or $\mathrm{M}_{5}$ displayed normal cochlear function, including threshold and suprathreshold responses for ABRs and DPOAEs, magnitude and time course of shock-evoked olivocochlear effects, and vulnerability to acoustic injury. The normality of DPOAEs indicates a normal endolymphatic potential (Mills, 2003) and thus normal strial function, despite previous studies reporting $\mathrm{M}_{3}$ mediated effects on $\mathrm{K}^{+}$flux in strial marginal cells (Wangemann et al., 2001). The normality of olivocochlear suppression and acoustic vulnerability suggests that ACh release from olivocochlear terminals is unaffected, despite previous studies suggesting $\mathrm{M}_{3}$ autoreceptors on efferent terminals (Safieddine et al., 1996). Evidence that our olivocochlear assay is sensitive to quantitative changes in neurotransmission is provided by previous demonstration that a $60 \%$ increase in $\alpha 9 \mathrm{nAChR}$ protein is mirrored by a $50 \%$ increase in efferent effect (Maison et al., 2002). Our qRT-PCR analysis in adult ears (Fig. 1C) suggests that the lack of phenotype in these $\mathrm{G}_{\mathrm{q}}$-coupled $\mathrm{mAChR}$ mutants does not reflect compensatory upregulation of other $\mathrm{G}_{\mathrm{q}}$ receptors. Given the fundamental difference in downstream effects of $\mathrm{G}_{\mathrm{i}^{-}}$ coupled versus $\mathrm{G}_{\mathrm{q}}$-coupled mAChRs (Wess, 1996), it seems unlikely that upregulation of $\mathrm{M}_{2}$ receptors compensates for loss of $\mathrm{M}_{3}$ or $\mathrm{M}_{5}$. Thus, the lack of in vivo phenotype casts significant doubt on a functional role for $\mathrm{G}_{\mathrm{q}}$-coupled $\mathrm{mAChRs}$, in either the normal or the noise-stressed adult cochlea.

Deletion of $\mathrm{G}_{\mathrm{i}}$-coupled $\mathrm{mAChRs}$, i.e., either $\mathrm{M}_{2}$ and/or $\mathrm{M}_{4}$, depressed suprathreshold neural amplitudes by $>25 \%$ (Fig. 6D). At low frequencies, DPOAEs were normal, whereas at high frequencies, DPOAEs were also slightly attenuated (Fig. 6A). At low frequencies, the purely "neural" phenotype is similar to that seen with deletion of $\alpha$ calcitonin gene-related peptide, a peptide transmitter colocalized with ACh in lateral olivocochlear terminals (Maison et al., 2003b). These terminals synapse with both inner hair cells and cochlear nerve terminals (Liberman, 1980) (Fig. 9), and both cell types express $\mathrm{M}_{2}$ and $\mathrm{M}_{4}$ receptors (Fig. 1). In vitro studies of muscarinic signaling in inner hair cells are lacking, but loss of the mAChR-mediated cation conductance in spiral ganglion cells (Ito and Dulon, 2002) could underlie the decreased neural excitability observed here in $\mathrm{M}_{2} / \mathrm{M}_{4}$ mutants (Fig. 6D). Presynaptic effects on ACh release must also be considered, given evidence for $\mathrm{M}_{2}$ receptors in olivocochlear terminals in the inner hair cell area (Fig. 2); however, presynaptic $\mathrm{M}_{2}$ receptors in other systems reduce ACh release, by binding of associated G-proteins to voltage-gated calcium channels (Brown and Sihra, 2008). Thus, effects of receptor deletion should be enhanced ACh release and greater neural excitability rather than the observed attenuation. Activation of lateral olivocochlear neurons in vivo can slowly enhance cochlear neural responses without changing DPOAEs (Groff and Liberman, 2003). These slow, excitatory effects may be mediated by postsynaptic muscarinic signaling in type I spiral ganglion cells, and their functional utility may be the binaural balancing of responses from the two ears that is required for accurate spatial localization of high-frequency sounds (Darrow et al., 2006).

At high frequencies, the dramatic reduction of noise-induced threshold shifts in the $\mathrm{M}_{2} / \mathrm{M}_{4}$ knock-out, especially in the DPOAEs (Fig. $8 D$ ), suggests a modulation of nicotinic effects in the outer hair cell area, given that activation of these nAChRs protects the ear from acoustic injury (Maison et al., 2002; Taranda et al., 2009), by increasing intracellular calcium concentration (Maison et al., 2007a). Our results suggest that mAChRs are not expressed in outer hair cells (Fig. 1); thus, the increased resistance is likely not attributable to the loss of postsynaptic receptors. Rather, the effect may reflect enhanced ACh release from olivocochlear terminals on outer hair cells attributable to the loss of presynaptic $\mathrm{M}_{2}$ receptors. Effects of the missing $\mathrm{mAChRs}$ may be too slow to be revealed by our 70 s olivocochlear assay (Fig. 7) but fast enough to dramatically impact the 15 or 120 min sound exposures used to induce temporary or permanent acoustic injury (Fig. 8).

Changes in brainstem circuitry driving the olivocochlear reflex could also contribute to enhanced noise resistance in the $\mathrm{M}_{2} / \mathrm{M}_{4}$ nulls, given that $\mathrm{M}_{2} \mathrm{mAChRs}$ are expressed in the cochlear nucleus (Yao et al., 1996). Indeed, mAChRs may mediate a positive feedback loop from descending olivocochlear collaterals to the same cochlear nucleus neurons supplying ascending input to the olivocochlear reflex (Fujino and Oertel, 2001). However, loss of putative feedback in the $\mathrm{M}_{2} / \mathrm{M}_{4}$ nulls should diminish olivocochlear activity and decrease noise resistance. Thus, present results suggest that the observed phenotype arises in the cochlea, which in turn suggests the novel idea that pharmacological manipulation of muscarinic signaling could significantly enhance the resistance of the inner ear to noise-induced hearing loss. 


\section{References}

Bartolami S, Ripoll C, Planche M, Pujol R (1993) Localization of functional muscarinic receptors in the rat cochlea: evidence for efferent presynaptic autoreceptors. Brain Res 626:200-209.

Blanchet C, Eróstegui C, Sugasawa M, Dulon D (1996) Acetylcholineinduced potassium current of guinea pig outer hair cells: its dependence on a calcium influx through nicotinic-like receptors. J Neurosci 16:2574-2584.

Brown DA, Sihra TS (2008) Presynaptic signaling by heterotrimeric G-proteins. Handb Exp Pharmacol 184:207-260.

Caulfield MP (1993) Muscarinic receptors-characterization, coupling and function. Pharmacol Ther 58:319-379.

Chen Z, Kujawa SG, Sewell WF (2007) Auditory sensitivity regulation via rapid changes in expression of surface AMPA receptors. Nat Neurosci 10:1238-1240.

Darrow KN, Maison SF, Liberman MC (2006) Cochlear efferent feedback balances interaural sensitivity. Nat Neurosci 9:1474-1476.

Darrow KN, Maison SF, Liberman MC (2007) Selective removal of lateral olivocochlear efferents increases vulnerability to acute acoustic injury. J Neurophysiol 97:1775-1785.

Derbenev AV, Linn CL, Guth PS (2005) Muscarinic ACh receptor activation causes transmitter release from isolated frog vestibular hair cells. J Neurophysiol 94:3134-3142.

Drescher DG, Upadhyay S, Wilcox E, Fex J (1992) Analysis of muscarinic receptor subtypes in the mouse cochlea by means of the polymerase chain reaction. J Neurochem 59:765-767.

Elgoyhen AB, Johnson DS, Boulter J, Vetter DE, Heinemann S (1994) Alpha 9: an acetylcholine receptor with novel pharmacological properties expressed in rat cochlear hair cells. Cell 79:705-715.

Elgoyhen AB, Vetter DE, Katz E, Rothlin CV, Heinemann SF, Boulter J (2001) Alpha10: a determinant of nicotinic cholinergic receptor function in mammalian vestibular and cochlear mechanosensory hair cells. Proc Natl Acad Sci U S A 98:3501-3506.

Erostegui C, Norris CH, Bobbin RP (1994) In vitro pharmacologic characterization of a cholinergic receptor on outer hair cells. Hear Res 74:135-147.

Eybalin M (1993) Neurotransmitters and neuromodulators of the mammalian cochlea. Physiol Rev 73:309-373.

Felix D, Ehrenberger K (1992) The efferent modulation of mammalian inner hair cell afferents. Hear Res 64:1-5.

Fuchs PA, Murrow BW (1992) Cholinergic inhibition of short (outer) hair cells of the chick's cochlea. J Neurosci 12:800-809.

Fujino K, Oertel D (2001) Cholinergic modulation of stellate cells in the mammalian cochlear nucleus. J Neurosci 21:7372-7383.

Gao J, Maison SF, Wu X, Hirose K, Jones SM, Bayazitov I, Tian Y, Mittleman G, Matthews DB, Zakharenko SS, Liberman MC, Zuo J (2007) Targeted deletion of glutamate receptor subunit $\delta 1$ causes high-frequency threshold elevation. Mol Cell Biol 27:4500-4512.

Gifford ML, Guinan JJ Jr (1983) Effects of crossed-olivocochlear-bundle stimulation on cat auditory nerve fiber responses to tones. J Acoust Soc Am 74:115-123.

Gomeza J, Zhang L, Kostenis E, Felder C, Bymaster F, Brodkin J, Shannon H, Xia B, Deng C, Wess J (1999a) Enhancement of D1 dopamine receptormediated locomotor stimulation in $\mathrm{M}_{4}$ muscarinic acetylcholine receptor knock-out mice. Proc Natl Acad Sci U S A 96:10483-10488.

Gomeza J, Shannon H, Kostenis E, Felder C, Zhang L, Brodkin J, Grinberg A, Sheng H, Wess J (1999b) Pronounced pharmacologic deficits in M2 muscarinic acetylcholine receptor knock-out mice. Proc Natl Acad Sci U S A 96:1692-1697.

Groff JA, Liberman MC (2003) Modulation of cochlear afferent response by the lateral olivocochlear system: activation via electrical stimulation of the inferior colliculus. J Neurophysiol 90:3178-3200.

Guinan JJ Jr (1996) The physiology of olivocochlear efferents. In: The cochlea (Dallos PJ, Popper AN, Fay RR, editors), pp 435-491. New York: Springer.

Guth PS, Norris CH, Guth SL, Quine DB, Williams WH (1986) Cholinomimetics mimic efferent effects on semicircular canal afferent activity in the frog. Acta Otolaryngol 102:194-203.

Hackney CM, Mahendrasingam S, Penn A, Fettiplace R (2005) The concentrations of calcium buffering proteins in mammalian cochlear hair cells. J Neurosci 25:7867-7875.

Hamilton SE, Loose MD, Qi M, Levey AI, Hille B, McKnight GS, Idzerda RL,
Nathanson NM (1997) Disruption of the m1 receptor gene ablates muscarinic receptor-dependent $\mathrm{M}$ current regulation and seizure activity in mice. Proc Natl Acad Sci U S A 94:13311-13316.

Heilbronn E, Järlebark L, Lawoko G (1995) Cholinergic and purinergic signaling in outer hair cells of mammalian cochlea. Neurochem Int 27:301-311.

Hequembourg S, Liberman MC (2001) Spiral ligament pathology: a major aspect of age-related cochlear degeneration in C57BL/6 mice. J Assoc Res Otolaryngol 2:118-129.

Housley GD, Ashmore JF (1991) Direct measurement of the action of acetylcholine on isolated outer hair cells of the guinea pig cochlea. Proc Biol Sci 244:161-167.

Ito K, Dulon D (2002) Nonselective cation conductance activated by muscarinic and purinergic receptors in rat spiral ganglion neurons. Am J Physiol Cell Physiol 282:C1121-C1135.

James WM, Cheatham MA, Klein WL (1983) Muscarinic acetylcholine receptor binding in the guinea pig cochlea. Hear Res 9:113-121.

Jositsch G, Papadakis T, Haberberger RV, Wolff M, Wess J, Kummer W (2009) Suitability of muscarinic acetylcholine receptor antibodies for immunohistochemistry evaluated on tissue sections of receptor genedeficient mice. Naunyn Schmiedebergs Arch Pharmacol 379:389-395.

Kakehata S, Nakagawa T, Takasaka T, Akaike N (1993) Cellular mechanism of acetylcholine-induced response in dissociated outer hair cells of guinea-pig cochlea. J Physiol 463:227-244

Khan KM, Drescher MJ, Hatfield JS, Khan AM, Drescher DG (2002) Muscarinic receptor subtypes are differentially distributed in the rat cochlea. Neuroscience 111:291-302.

Krishnaswamy A, Cooper E (2009) An activity-dependent retrograde signal induces the expression of the high-affinity choline transporter in cholinergic neurons. Neuron 61:272-286.

Kujawa SG, Glattke TJ, Fallon M, Bobbin RP (1992) Intracochlear application of acetylcholine alters sound-induced mechanical events within the cochlear partition. Hear Res 61:106-116.

Liberman MC (1980) Efferent synapses in the inner hair cell area of the cat cochlea: an electron microscopic study of serial sections. Hear Res 3:189-204.

Lippe WR, Zirpel L, Stone JS (2002) Muscarinic receptors modulate intracellular $\mathrm{Ca}^{2+}$ concentration in hyaline cells of the chicken basilar papilla. J Comp Physiol A Neuroethol Sens Neural Behav Physiol 188:381-395.

Maison SF, Luebke AE, Liberman MC, Zuo J (2002) Efferent protection from acoustic injury is mediated via $\alpha 9$ nicotinic acetylcholine receptors on outer hair cells. J Neurosci 22:10838-10846.

Maison SF, Adams JC, Liberman MC (2003a) Olivocochlear innervation in the mouse: immunocytochemical maps, crossed versus uncrossed contributions, and transmitter colocalization. J Comp Neurol 455:406-416.

Maison SF, Emeson RB, Adams JC, Luebke AE, Liberman MC (2003b) Loss of alpha CGRP reduces sound-evoked activity in the cochlear nerve. J Neurophysiol 90:2941-2949.

Maison SF, Rosahl TW, Homanics GE, Liberman MC (2006) Functional role of the cochlea's GABAergic innervation: phenotypic analysis of mice lacking $\mathrm{GABA}_{\mathrm{A}}$ receptor subunits $\alpha 1, \alpha 2, \alpha 5, \alpha 6, \beta 2, \beta 3$, or $\delta$. J Neurosci 26:10315-10326.

Maison SF, Parker LL, Young L, Adelman JP, Zuo J, Liberman MC (2007a) Overexpression of SK2 channels enhances efferent suppression of cochlear responses without enhancing noise resistance. J Neurophysiol 97:2930-2936.

Maison SF, Vetter DE, Liberman MC (2007b) A novel effect of cochlear efferents: in vivo response enhancement does not require $\alpha 9$ cholinergic receptors. J Neurophysiol 97:3269-3278.

Merchan MA, Collia F, Lopez DE, Saldaña E (1988) Morphology of cochlear root neurons in the rat. J Neurocytol 17:711-725.

Mills DM (2003) Differential responses to acoustic damage and furosemide in auditory brainstem and otoacoustic emission measures. J Acoust Soc Am 113:914-924.

Niedzielski AS, Ono T, Schacht J (1992) Cholinergic regulation of the phosphoinositide second messenger system in the guinea pig organ of Corti. Hear Res 59:250-254.

Rome C, Luo D, Dulon D (1999) Muscarinic receptor-mediated calcium signaling in spiral ganglion neurons of the mammalian cochlea. Brain Res 846:196-203.

Roux I, Safieddine S, Nouvian R, Grati M, Simmler MC, Bahloul A, Perfettini I, Le Gall M, Rostaing P, Hamard G, Triller A, Avan P, Moser T, Petit C 
(2006) Otoferlin, defective in a human deafness form, is essential for exocytosis at the auditory ribbon synapse. Cell 127:277-289.

Safieddine S, Bartolami S, Wenthold RJ, Eybalin M (1996) Pre- and postsynaptic M3 muscarinic receptor mRNAs in the rodent peripheral auditory system. Mol Brain Res 40:127-135.

Shigemoto T, Ohmori H (1991) Muscarinic receptor hyperpolarizes cochlear hair cells of chick by activating $\mathrm{Ca}^{2+}$-activated $\mathrm{K}^{+}$channels. J Physiol 442:669-690.

Sridhar TS, Liberman MC, Brown MC, Sewell WF (1995) A novel cholinergic "slow effect" of efferent stimulation on cochlear potentials in the guinea pig. J Neurosci 15:3667-3678.

Sridhar TS, Brown MC, Sewell WF (1997) Unique postsynaptic signaling at the hair cell efferent synapse permits calcium to evoke changes on two time scales. J Neurosci 17:428-437.

Stankovic KM, Corfas G (2003) Real-time quantitative RT-PCR for lowabundance transcripts in the inner ear: analysis of neurotrophic factor expression. Hear Res 185:97-108.

Sziklai I, He DZ, Dallos P (1996) Effect of acetylcholine and GABA on the transfer function of electromotility in isolated outer hair cells. Hear Res 95:87-99.

Taranda J, Maison SF, Ballestero JA, Katz E, Savino J, Vetter DE, Boulter J, Liberman MC, Fuchs PA, Elgoyhen AB (2009) A point mutation in the hair cell nicotinic cholinergic receptor prolongs cochlear inhibition and enhances noise protection. PLoS Biol 7:e18.

Thiers FA, Nadol JB Jr, Liberman MC (2008) Reciprocal synapses between outer hair cells and their afferent terminals: evidence for a local neural network in the mammalian cochlea. J Assoc Res Otolaryngol 9:477-489.

van Megen YJ, Klaassen AB, Rodrigues de Miranda JF, Kuijpers W (1988) Cholinergic muscarinic receptors in rat cochlea. Brain Res 474:185-188.

Verbitsky M, Rothlin CV, Katz E, Elgoyhen AB (2000) Mixed nicotinicmuscarinic properties of the alpha9 nicotinic cholinergic receptor. Neuropharmacology 39:2515-2524.

Vetter DE, Liberman MC, Mann J, Barhanin J, Boulter J, Brown MC, SaffioteKolman J, Heinemann SF, Elgoyhen AB (1999) Role of alpha9 nicotinic ACh receptor subunits in the development and function of cochlear efferent innervation. Neuron 23:93-103.

Vetter DE, Katz E, Maison SF, Taranda J, Turcan S, Ballestero J, Liberman
MC, Elgoyhen AB, Boulter J (2007) The alpha10 nicotinic acetylcholine receptor subunit is required for normal synaptic function and integrity of the olivocochlear system. Proc Natl Acad Sci U S A 104:20594-20599.

Wang Y, Hirose K, Liberman MC (2002) Dynamics of noise-induced cellular injury and repair in the mouse cochlea. J Assoc Res Otolaryngol $3: 248-268$

Wangemann P, Liu J, Scherer EQ, Herzog M, Shimozono M, Scofield MA (2001) Muscarinic receptors control $\mathrm{K}^{+}$secretion in inner ear strial marginal cells. J Membr Biol 182:171-181.

Warr BW (1992) Organization of olivocochlear efferent systems in mammals. In: Mammalian auditory pathway: neuroanatomy (Webster DB Popper AN, Fay RR, eds), pp 410-428. New York: Springer.

Warr WB, Guinan JJ Jr (1979) Efferent innervation of the organ of Corti: two separate systems. Brain Res 173:152-155.

Wess J (1996) Molecular biology of muscarinic acetylcholine receptors. Crit Rev Neurobiol 10:69-99.

Wess J (2004) Muscarinic acetylcholine receptor knockout mice: novel phenotypes and clinical implications. Annu Rev Pharmacol Toxicol 44:423450

Wiederhold ML, Kiang NY (1970) Effects of electric stimulation of the crossed olivocochlear bundle on single auditory-nerve fibers in the cat. J Acoust Soc Am 48:950-965.

Yamada M, Lamping KG, Duttaroy A, Zhang W, Cui Y, Bymaster FP, McKinzie DL, Felder CC, Deng CX, Faraci FM, Wess J (2001a) Cholinergic dilation of cerebral blood vessels is abolished in $\mathrm{M}_{5}$ muscarinic acetylcholine receptor knock-out mice. Proc Natl Acad Sci U S A 98:14096-14101.

Yamada M, Miyakawa T, Duttaroy A, Yamanaka A, Moriguchi T, Makita R, Ogawa M, Chou CJ, Xia B, Crawley JN, Felder CC, Deng CX, Wess J (2001b) Mice lacking the M3 muscarinic acetylcholine receptor are hypophagic and lean. Nature 410:207-212.

Yao W, Godfrey DA, Levey AI (1996) Immunolocalization of muscarinic acetylcholine subtype 2 receptors in the rat cochlea nucleus. J Comp Neurol 373:27-40.

Zhang W, Basile AS, Gomeza J, Volpicelli LA, Levey AI, Wess J (2002) Characterization of central inhibitory muscarinic autoreceptors by the use of muscarinic acetylcholine receptor knock-out mice. J Neurosci 22:17091717. 